\title{
Samen werken aan goed onderwijs
}

Citation for published version (APA):

Schils, T. (2021). Samen werken aan goed onderwijs: benut die complementariteit! Maastricht University. https://doi.org/10.26481/spe.20210520ts

Document status and date:

Published: 20/05/2021

DOI:

$10.26481 /$ spe.20210520ts

Document Version:

Publisher's PDF, also known as Version of record

\section{Please check the document version of this publication:}

- A submitted manuscript is the version of the article upon submission and before peer-review. There can be important differences between the submitted version and the official published version of record.

People interested in the research are advised to contact the author for the final version of the publication, or visit the DOI to the publisher's website.

- The final author version and the galley proof are versions of the publication after peer review.

- The final published version features the final layout of the paper including the volume, issue and page numbers.

Link to publication

\footnotetext{
General rights rights.

- You may freely distribute the URL identifying the publication in the public portal. please follow below link for the End User Agreement:

www.umlib.nl/taverne-license

Take down policy

If you believe that this document breaches copyright please contact us at:

repository@maastrichtuniversity.nl

providing details and we will investigate your claim.
}

Copyright and moral rights for the publications made accessible in the public portal are retained by the authors and/or other copyright owners and it is a condition of accessing publications that users recognise and abide by the legal requirements associated with these

- Users may download and print one copy of any publication from the public portal for the purpose of private study or research.

- You may not further distribute the material or use it for any profit-making activity or commercial gain

If the publication is distributed under the terms of Article $25 \mathrm{fa}$ of the Dutch Copyright Act, indicated by the "Taverne" license above, 


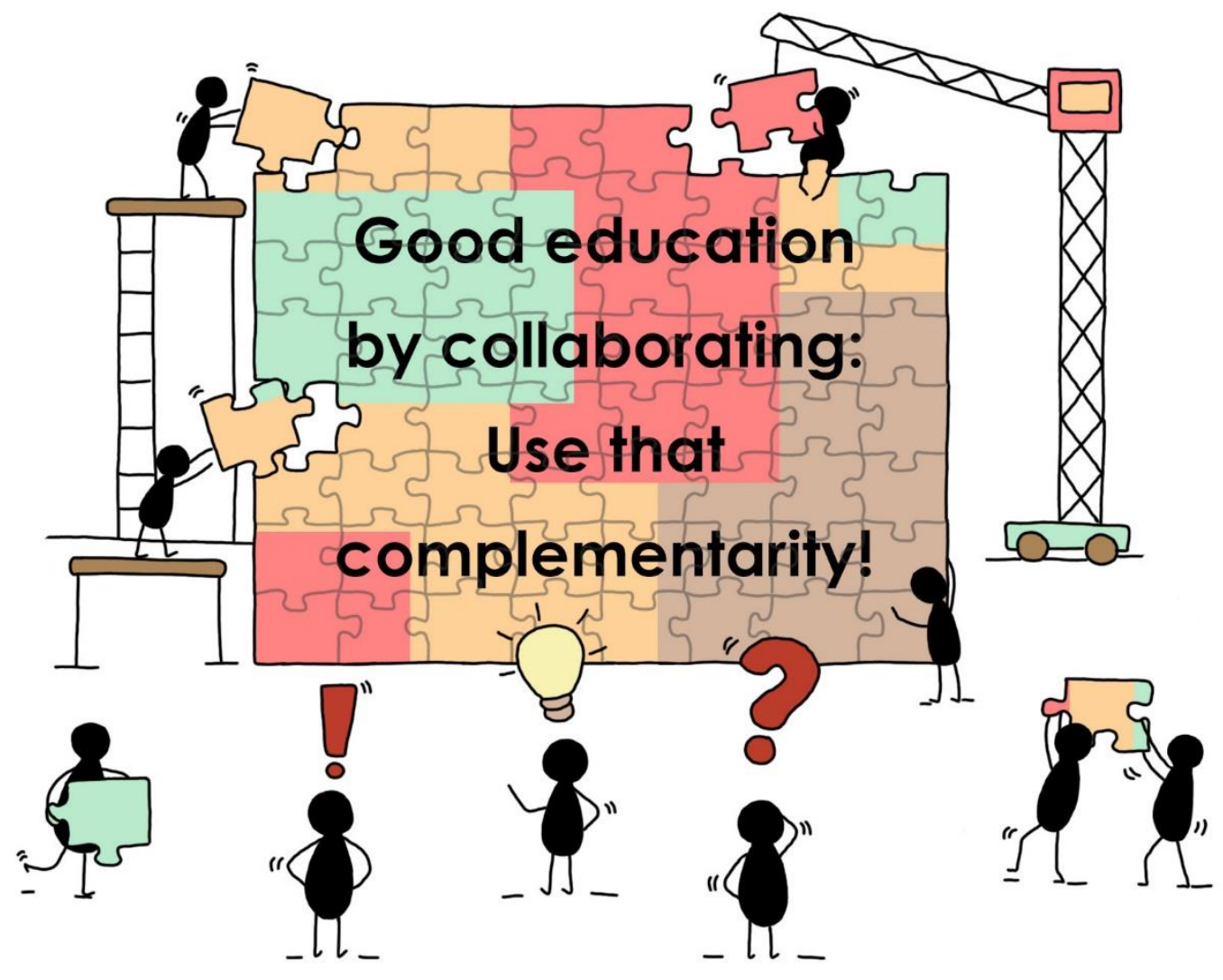

Trudie Schils

Inaugural lecture

May 20, 2021

School of Business and Economics 
(C) Text and illustrations Trudie Schils 2021. All rights reserved.

This publication is an English translation of the inaugural lecture held in Dutch. 


\section{Good education by collaborating: Use that complementarity!}

Inaugural lecture given upon the public acceptance of the appointment as Professor of Economics of Education at the School of Business and Economics, Maastricht University.

Maastricht, May 20, 2021

Trudie Schils 

Highly esteemed Rector,

dear colleagues and others,

dear family and friends,

\section{A changed demand for skills}

Education has a central role in our society. It fosters economic development and growth. It contributes to a healthy population. Good education provides children and students of all ages with the skills and knowledge they need for their further development. The demand for these skills has changed over time, for example, because of technological developments. Computers and robots mainly take over routine tasks that people perform at work. This leads to cheaper and higher quality products, as the computers are more precise and produce with fewer errors than human beings'. Recent developments show that also non-routine tasks are taken over by technology, mostly because of the availability of large datasets and the use of artificial intelligence 2 .

While these developments cause certain tasks at work to disappear, they also lead to the introduction of new tasks. These are tasks that call for human perception, creativity or social skills 3 . Colleagues Didier Fouarge, Jim Allen, Barbara Belfi and Lex Borghans show in various studies that there is a growth in the number of jobs that require problem-solving and digital skills ${ }^{4}$. Digital skills include programming and the analysis of large-scale datasets, but also using technology to communicate, which has shown to be of high relevance due to the COVID-19 pandemic.

Research shows that also other types of skills are important for later life success. International colleagues Marion Spengler, Rodica Damian and Brent Roberts show that, among others, responsible behaviour and interest in school are important predictors of labour market success, next to cognitive skills (e.g., reading and math), intelligence, socio-economic status and personality5. Among personality traits, especially openness to experience and conscientiousness are often mentioned'. People who score higher on openness to experience show to be more creative, intellectually curious and interested in new experiences and ideas. Conscientiousness relates to being organised, disciplined and hardworking,

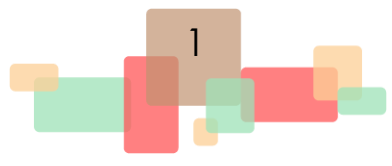


but also to showing responsibility for one's own actions and behaviour. Emotional stability is also an important personality trait. Research shows that people who are more emotionally stable show more positive coping strategies when confronted with sudden challenges, such as the recent COVID-19 pandemic 7 .

This insight in the changing demand for certain types of skills has important implications for education. Good education provides students with a broad set of skills and knowledge, that enable them to get a good job and live a healthy and happy life. Recently, there has been a lot of attention for the quality of Dutch education. On the one hand, concerns have been raised about the learning and development losses due to the measures taken because of the COVID-19 pandemic (e.g., school closures and social distancing). On the other hand, evidence shows more general skill shortages among students, e.g., in the domain of language and reading, but also in the domain of self-regulation, critical thinking, collaboration and dealing with emotions or uncertainty. With a given amount of time that students can spend at school, choices must be made with respect to the offered curriculum. To facilitate this decision-making, knowledge and insight is needed about the importance of the various skills for school and later life outcomes, but also on how to assess and develop these skills in education.

In my opinion, for acquiring this knowledge and insights, four ingredients are crucial:

1. Understanding of the theories that explain the role and development of skills.

2. Use of proper data and empirical methods to study relevant relations.

3. Multidisciplinary approach where the role and development of skills are studied from various scientific disciplines.

4. Collaboration between educational research and practice.

By using the complementarity of these four ingredients, as well as the complementary perspectives within these ingredients, thorough knowledge and insights are developed about further improvement of the relevant skills among students. This is central in the approach that I take in the research in my chair "Economics of Education". 
I distinguish between four research domains:

1. The relevance of different skills in education.

2. Differences in skills between groups of students.

3. The assessment of various skills in education.

4. The development of relevant skills in education.

I will briefly give examples to describe these four research domains.

\section{The relevance of different skills in education}

The first research domain I will contribute to in the coming years is research on what skills are most relevant in education, i.e., the relation between various skills and educational outcomes in the short and the long run. In general, we can distinguish between three types of skills:

* Cognitive skills such as reading, writing, math, but also problem-solving and digital skills.

* Interpersonal skills such as collaboration, communication, presentation, leadership, and empathy.

* Intrapersonal skills, such as the ability to reflect on one's own behaviour, take responsibility, adapt to new situations, have realistic expectations, and make choices.

The last two groups of skills are often taken together as social-emotional skills.

Research shows that not only cognitive skills are important for learning and educational outcomes, but that social-emotional skills also play an important role. An common instrument used in education to assess how students are performing is the achievement test. To perform well on such a test, more is needed than sufficient knowledge about the subject tested. In the past years, a great deal of research has been done to analyse what additional factors play a role. Studies point to the relevance of motivation, personality, curiosity or self-control 8 .

Together with Lex Borghans, I analysed patterns in students' achievement test scores'. We observed that students performed better at the start of a test, than at the end of the test (see Figure 1). In other words, the probability that a question was answered correctly was lower the later the question was asked in the test. A logical explanation would be that the test questions 
become more difficult towards the end of the test, yet this was not the case for the tests we used for the research. The various test questions are offered to students in a different order. Where student $A$ has a given question as a second question, student $B$ has this question as the sixteenth question. The different versions of the test are randomly assigned to students. This means that the decline in test performance is not being caused by more difficult questions. But what factors do relate to this decline in test performance?

Figure 1: Test performance during a test

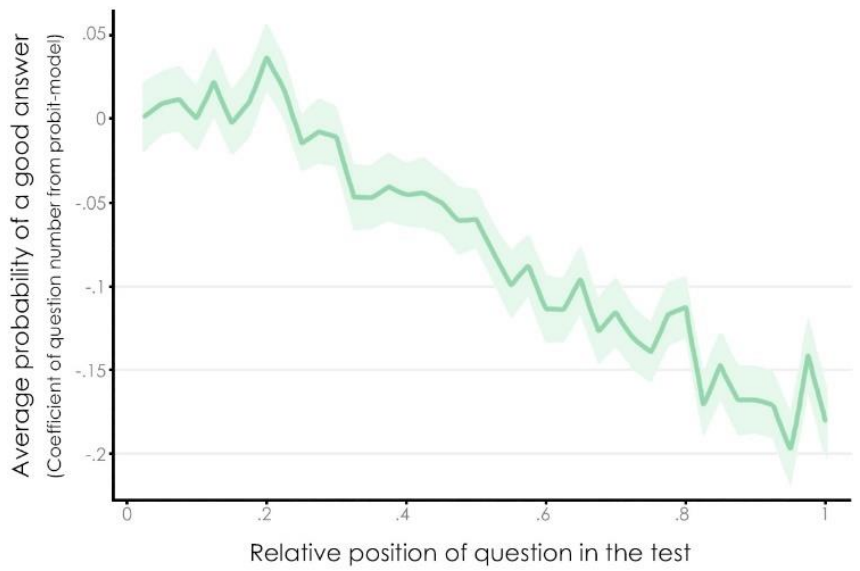

This figure shows the coefficients of a probit-model for the correct answer on a question, given the position and difficulty of the question. The question with mean difficulty is taken as a reference. Data used are PISA (2006). For more information see Borghans \& Schils $(2018)^{9}$.

To analyse this, we combined test scores with student characteristics, including information about students' personality. We find that performance at the start of the test is mostly related to cognitive skills and the personality trait openness to experience. The performance decline is related to other factors, mostly conscientiousness, agreeableness and need for achievement. Students who are more conscientious, more agreeable or have a higher need for achievement show a lower performance decline compared to students who score lower on these traits. It is important to understand which factors play a role, as it determines the intervention that is needed to foster students' performance. Low

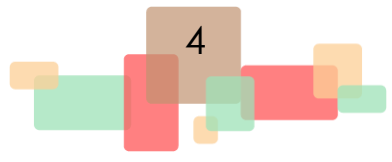


performance that is the result of a shortage of knowledge calls for a different approach than low performance that is the result of certain socialemotional skills.

In the search for a suitable approach for low student performance it is also important to study longer term relations between skills and outcomes. It can reveal important early indicators of undesirable outcomes. School dropout, for example, is such an undesirable outcome. Students who drop out of school without a diploma, generally experience large difficulties in finding or keeping a job ${ }^{10}$. They also have a higher risk of ending up in crime or having an unhealthy life style'1. Colleague Mark Levels, among others, shows that next to students' socioeconomic background, aspects such as low resilience or low and unrealistic expectations are important predictors of school dropout ${ }^{12}$.

In a study together with Ron Diris and stakeholders from municipalities, secondary and medium vocational education, we further investigated early indicators for school dropout13. We looked back in time for students who dropped out of school at the end of secondary school or in the first years of medium vocational education and for those who did not do so. When we look at cognitive school performance of the two groups at the end of primary school (grade 6), we find that the dropouts show higher performance in language and calculation compared to the non-dropouts (see Figure 2). In particularly, scores on the calculation test are higher for the dropouts. At the IQ-test, both groups perform equally. When we look at test scores three years later, when students are in secondary school (grade 9), we observe much worse performance of the later dropouts. Test scores in calculation are now comparable to those of the non-dropouts, but language test scores are much worse. 
Figure 2: Cognitive school performance in primary and secondary school of early school dropouts compared to non-dropouts

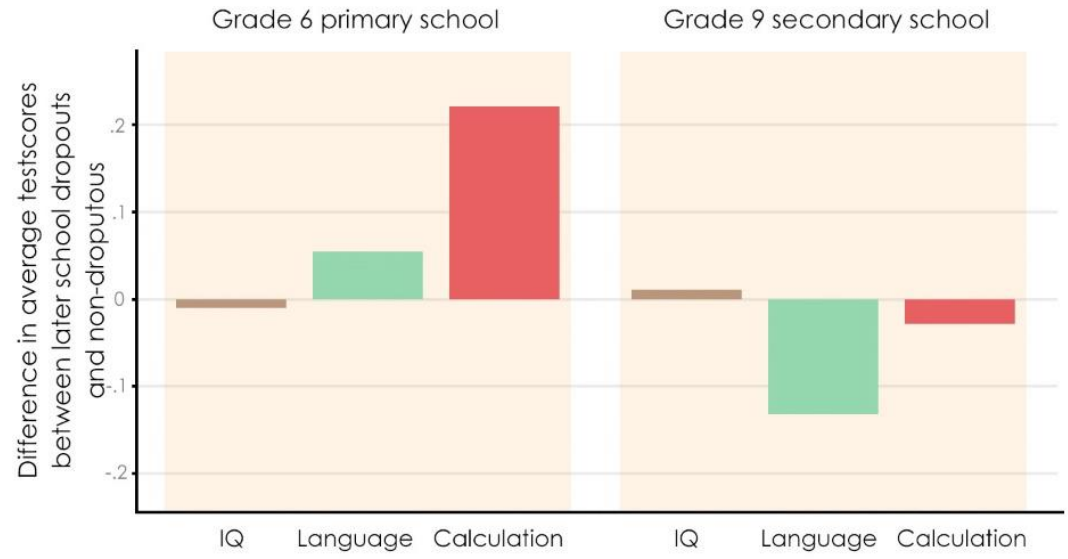

This figure shows the difference in test scores between the students that at a later point in time drop out without a qualification and those who do not drop out. Differences are denoted in standard deviations. Data stem from the Onderwijs Monitor Limburg (2009-2016), supplemented with register data from municipalities. For more information see Diris \& Schils $(2017)^{13}$.

Next to test scores, we also looked at personality traits of both groups of students. At the end of primary school, we already see that both groups have different (average) personalities (see Figure 3). Students in the dropout group show lower scores on conscientiousness, agreeableness, emotional stability, and perseverance at the end of primary school. They score a bit higher on openness to experience and need for achievement. When we look at the same traits in grade 9 of secondary school, the group dropouts show even lower conscientiousness and perseverance. Moreover, they now score lower on need for achievement in comparison with the other students. Earlier we already saw the importance of conscientiousness as a predictor for later life outcomes. Interesting is that the dropouts now score higher on emotional stability compared to the other students.

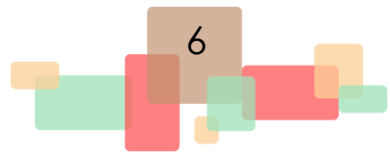


Figure 3: Personality traits of dropouts and non-dropouts in primary and secondary school

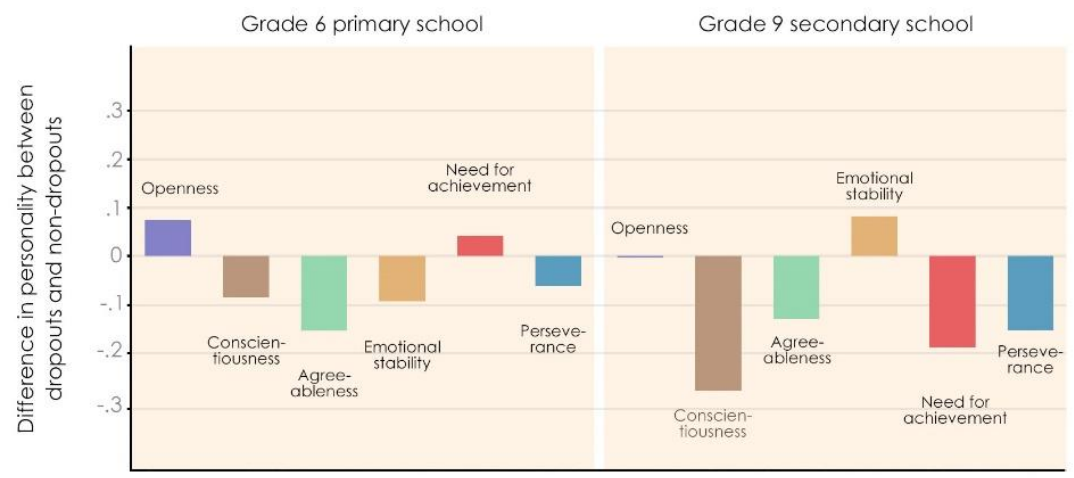

This figure shows the difference in personality traits between the students that at a later point in time drop out without a qualification and those who do not drop out. Differences are denoted in standard deviations. Data stem from the OnderwijsMonitor Limburg (2009-2016), supplemented with register data from municipalities. For more information see Diris \& Schils $(2017)^{13}$

The results lead to some important and unanswered questions that call for further research. What causes the drop in cognitive test scores and in some personality traits of the students in the dropout group? What does the higher emotional stability in grade 9 mean? Trait interactions are also of importance to study. Together with Caroline Wehner I show that higher conscientiousness can mitigate some of the negative effects of low emotional stability among low achievers in education ${ }^{14}$.

This research shows that there is still a lot to learn, but it also shows that if you would only look at cognitive skills at the end of primary school, the risk group for dropout would not necessarily be identified. It is important to understand such longer term relations and learn what students need in various phases of their development. This facilitates decision-making in what to offer in school and supports the early identification of groups at risk. This brings me at the second research domain that I am interested in: research about differences between groups of students. 


\section{Differences in skills between groups of students}

A lot of attention is being paid to inequalities in education, both among researchers and educational policymakers. In the Netherlands, part of this debate centers around the transition from primary to secondary school, when the tracking takes place. Research shows that students' socioeconomic background plays a large role both in the tracking decision and the development in the first years of secondary school. Students from lower socioeconomic backgrounds that have equal cognitive skills compared to students from higher socioeconomic backgrounds, receive a lower track recommendation, are more likely to be placed in a lower track when entering secondary school, and show higher downward mobility rates in the first years of secondary school 15 .

Inequality in education is a complex problem, with many factors being relevant. Research shows that social-emotional skills such as the ability of self-regulation, motivation or self-concept of students are important determinants for the tracking recommendation or students' development in secondary school ${ }^{16}$. In this phase of their lives, the young adolescents also experience major physical and social-emotional developments. They grow faster and enter puberty, which makes some students feel less confident, while others gain more confidence. They strive for more independence and are searching for their own identities. In doing so, they re-calibrate their relationships with adults, behave rebellious, but at the time show dependence, vulnerability, and sensitivity to criticism. These developments also affect their school performance ${ }^{17}$. Other studies point to the importance of the influence of relationships that students have, with friends, schoolmates, teachers and family 18 . In a study with Franziska Schwabe and Roxanne Korthals, I show, for example, that having good relationships with teachers contributes to the self-concept of students in the first years of secondary school19. Bart Golsteyn and colleagues show that the personality of peers affects students' performance in higher education ${ }^{20}$.

Expectations are also of relevance for student performance. Together with students Liza Gordin and Elke Claes I analysed expectations of students in grade 9 of two pre-higher education tracks ${ }^{21}$. We distinguished between students whose parents completed higher education, and students whose parents did not do so (i.e, prospective first generation students). When we 
look at the mean test scores of these two groups of students, we find that they perform equally (see Figure 4).

Figure 4: Cognitive school performance of students in grade 9 of pre-higher education tracks, in relation to their parents' education level

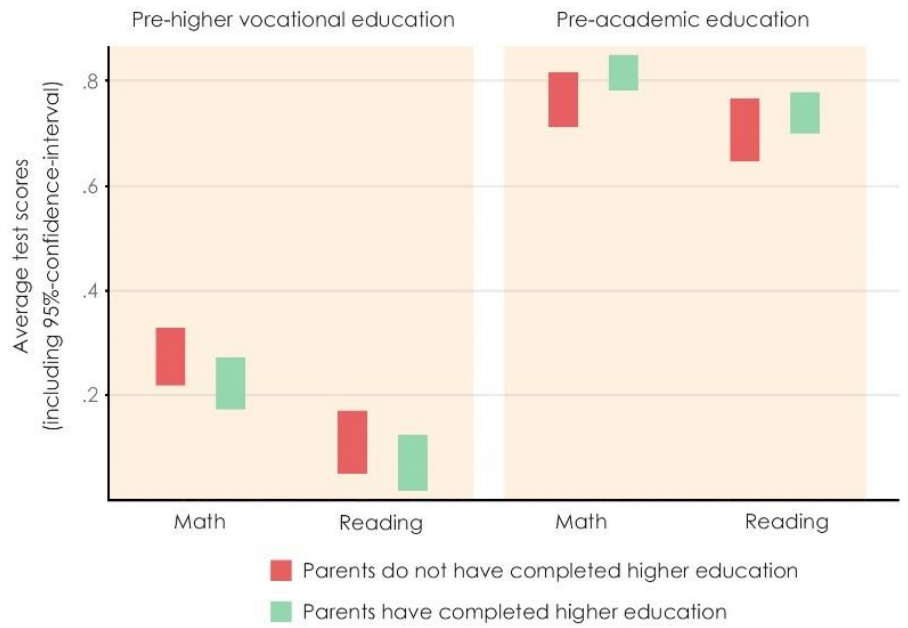

This figure shows the difference in test scores between students in the pre-higher education tracks whose parents have completed higher education and whose parents have not done so. The blocks are the total of the mean plus the $95 \%$-confidence-intervals on both sides. The vertical axis shows the predicted mean test scores after a linear regression of parental education on test scores. Tests were equal for both tracks and all schools and developed for cohort studies (including questions from PISA, COOL). Data stem from the OnderwijsMonitor Limburg (2014-2016).

When we ask both students and parents about their expectations for getting a higher education diploma, we observe some interesting differences. Students have relatively high expectations and we do not observe a difference between the two groups (see Figure 5). Parents in both groups generally have lower expectations, but more interestingly we observe a significant difference between the two groups. Parents without a higher education diploma have lower expectations compared to parents that completed higher education, even though the children of both groups performed equally on cognitive tests. This explorative study raises many questions. What is behind these differences? Some studies point

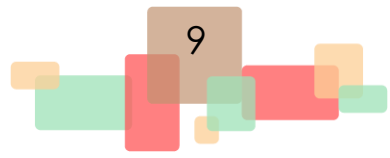


to the relevance of acquiring and digesting information or dealing with uncertainty22. What can be done to enhance the situation? In the coming years I will, together with Bart Golsteyn and Giulia Piccillo, supervise Brian Korthout in his PhD. research on this topic.

Figure 5: Future expectations of students (and their parents) in pre-higher education tracks in relation to their parents' education level

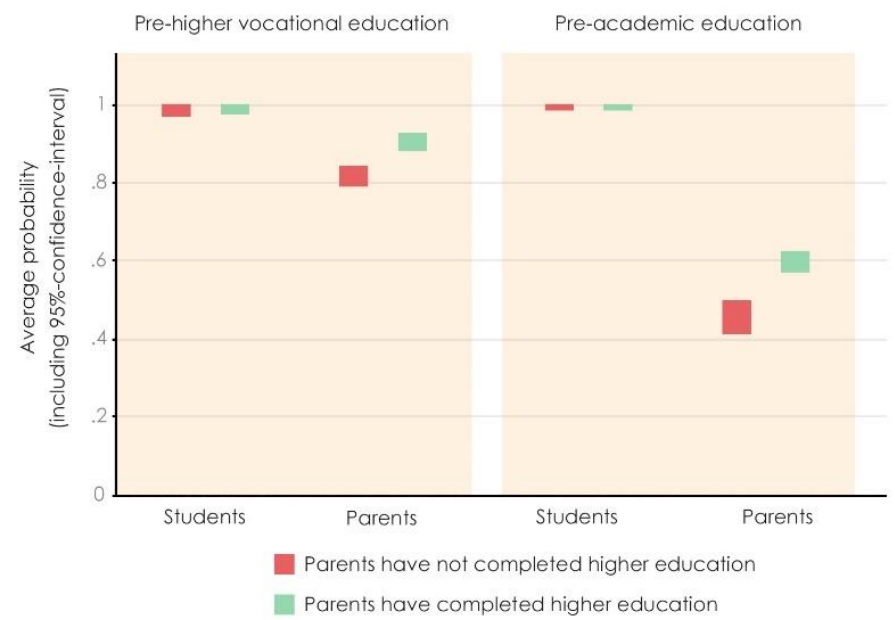

This figure shows the difference in expectations to get a diploma of higher education between students/parents in the pre-higher education tracks whose parents have completed higher education and whose parents have not done so. The blocks are the total of the mean plus the $95 \%$-confidence-intervals on both sides. The vertical axis shows the predicted probability of students/parents to get a higher education diploma. In the prehigher vocational education students/parents are asked for the likelihood of a diploma of higher vocational education or higher. In the pre-academic track students/parents are asked for the likelihood of an academic degree. Data stem from the OnderwijsMonitor Limburg (2014-2016).

Understanding the reasons for differences in educational performance between groups is crucial for the identification of risk groups, for the development of interventions in support of their learning, and for the reduction of inequalities in education. It is important to look beyond differences in cognitive performance, i.e., analyse differences in socialemotional skills and relevant interactions between different types of skills. Another important aspect is knowledge on how to assess the different skills.

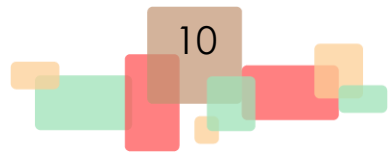


This characterises the third research domain I am interested in: research about the assessment of various skills.

\section{The assessment of various skills in education}

Tests are the most commonly used instrument in education to assess whether students know what they should know, and which students underor overperform. Different types of tests are used. Teachers regularly use their own tests, to see whether students understood what they taught in class. In this way, only students within the same class can be compared to each other. In addition, the methods used in class often come with specific assessments, and the performance of students from different classes or schools that use the same method, can be compared.

Next to these more specific tests, more general standardised tests are used. These are developed outside the school by test institutes and are the same for all schools. These tests are generally used to see how students on average perform on a given subject, such as language or math, and signal whether students' performance is in line with the goals set for education. Standardised tests allow a comparison with a national average, also over time. Moreover, they facilitate the comparison between schools and provide information about the quality of education ${ }^{23}$.

The systematic use of standardised tests in education, i.e., using tests that are explicitly developed for the given age and level of the student, enables the analysis of students' performance over time, and an assessment of whether a student performs in accordance with what was expected. It also enables a comparison between subjects. Based on these analyses, teachers can decide what additional support students need in their learning development. In what direction should the student develop and what is the level he should reach? What is needed to support his development? Recent practice in education shows that teachers answer these questions more often together with students. This formative evaluation of a student's learning development provides both teachers and students with insight into the student's learning process and not only into the results. Together with Sylvia Heeneman I supervise Lars Goertzen, a primary school teacher who implements and analyses formative evaluation

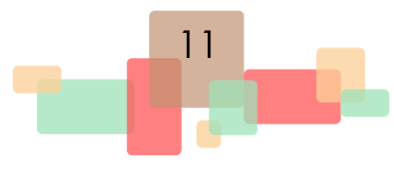


in grade 5 as part of his PhD. Jointly with other teachers he develops an approach for formative evaluation that fits this specific age group of students 24 .

Involving students in the evaluation of their own learning process fits the development of self-regulation in education, which is frequently mentioned as being an important skill for positive learning outcomes. Self-regulation refers to the ability of regulating and steering one's own behaviour, such as setting achievable goals and having realistic expectations. It is also about adapting to changed situations and dealing with uncertainty or negative experiences. Colleague Anique de Bruin shows that self-regulation is an important factor in the development of students in higher education 25 . Other studies reveal that also among younger students fostering selfregulated learning contributes to better school performance and higher motivation of students 26 .

Thinking back about my own school reports in primary school, teachers often commented on these aspects on my report cards. I see comments as "Trudie really tries her best", but also "Trudie should concentrate a bit more and work at a slower pace". These were just remarks, no formal assessments. When I now look at the report cards that my nephew Kaja received when he was in primary school, I see that specific skills are listed, e.g., collaboration, taking responsibility, dealing with emotions, selfconfidence, and getting along with classmates and teachers. These skills are explicitly judged by the teacher and are part of the overall assessment of a student's learning development. Teacher judgments are not based on tests but rely on the knowledge and experiences of the teachers. Research with several colleagues, among which Eva Feron and Bas ter Weel, shows that a teacher's judgment is predictive of a student's learning development, next to cognitive test scores ${ }^{27}$. These judgments are, just like test scores, not perfect. The learning potential of low-achievers, boys, ethnical minorities, or students from lower socio-economic background are frequently underestimated by teachers 28 .

Differences between the expected and real performance of students can be the result of explicit or implicit stereotypes, of a conservative attitude of teachers, or from differences in the context in which the judgment is made. For a study together with, among others, Jessika Golle, I studied the 
literature on teacher judgments of gifted students 29 . When teachers are asked to define a gifted student in general, they explicitly mention the vulnerability of gifted students, next to high cognitive performance and intelligence. They argue that giftedness often goes along with low emotional stability, behavioural problems in class, and low social skills. However, when teachers are asked to nominate students for enrichment programs in school, mostly high-performing and non-vulnerable students are mentioned. One could question whether teachers implicitly consider the probability of success that the student might have in the enrichment program, using expectations about the social-emotional skills of the gifted students. Such factors might also play a role in the lower tracking recommendations for students from a lower socio-economic background.

It is unclear how teachers assess students' social-emotional skills, or what the subjective assessment really means. Yet, given the importance of social-emotional skills, a correct judgment is crucial. Teachers often say that they use their intuition in such assessments: "he will make it". An intuitive approach, however, does not provide a solid base for a systematic analysis of a student's development. Some teachers use instruments for the assessment of students' social-emotional skills in school. Usually, they are asked to describe 'common behaviour' of students, and it can be questioned what this means in relation to the competence of students, and how valid this assessment is ${ }^{30}$. What behaviour is expected from students at different ages? What norm exists? What is the difference between "good" and "very good"? Does every teacher mean the same with "good"? The judgments and approaches not only differ between teachers, but teachers might even apply them differently among students. These differences are sometimes correct, yet sometimes arise from conscious or unconscious biases.

Within my chair 'Economics of Education' I will contribute to research about how teachers form their judgment of students' social-emotional skills and what these judgments mean. To provide teachers with practical instruments in their judgment, part of chair is an endowed chair (0.2 fte), financed by the Solberg-Verlinden Foundation and facilitated by the University Fund. 
Wiel Solberg started as a primary school teacher, followed by a few years as a math teacher in secondary school, after which he became the principal of a gymnasium. In 1968 he was the first director of CITO, the Dutch institute for test development, and he maintained this position until he retired in 1983. Solberg was very much interested in the measurement and registration of student performance and followed the work of psychologist Adriaan de Groot, the founder of the Dutch end of primary school test ("Citotest") 31. In 1994 Solberg founded, together with his wife Toos Verlinden, the Solberg-Verlinden Foundation, that aimed to foster the innovation of assessment of student performance. He has been very influential in the Netherlands, in the domain of objectification of student performance ${ }^{32}$. In the endowed chair I will continue that tradition, applied to the assessment of students' social-emotional skills. In 1970 Solberg made the following statement on the objectification of students' cognitive skills, that is of interest in this respect (freely translated) ${ }^{32}$ :

"With the term objectification one often aims at something absolute: an
absolute objectivity. In his 'Methodology' De Groot talks about a general
norm for objectivity, that, according to him, means that the researcher
should act as objectively as possible, i.e., without the interference of personal
opinions, preferences, observation methods, beliefs, interests, and feelings. In
this description one clearly sees that a general norm for objectivity can only
exist within the individual possibilities of the researcher. It must be clear that I
prefer talking about objectification rather than objectivity. For objectification
one must eliminate disturbing factors. Especially when there are a lot of
disturbing factors, we will never succeed in eliminating them all ...".

The specific goal of the endowed chair is to find or develop instruments that facilitate the teacher to objectivise his subjective judgment of students' social-emotional skills, in particular students aged between 10 and 14 years. I will explicitly do this in collaboration with teachers, as the instruments need to be useful for them in their daily practice. At the same time, the instruments should be valid and based on a clear norm that enables the comparison of the assessment between teachers and between students.

The developed instruments fit in the jargon of teachers, and operate as a standard, which is recognised in the field. Consequently, they can be used in the learning development of students, not only by the teacher, but also by others involved in this development. Moreover, the instruments support

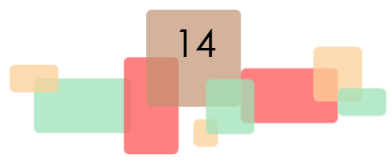


the evaluation of interventions targeted at students' social-emotional learning. That brings me to the fourth and final research domain that is central in my chair: how can relevant skills in education be developed among students?

\section{The development of relevant skills in education}

With the research I want to contribute to evidence-informed education. In the past years, a growing number of social-emotional learning programs have been developed ${ }^{33}$. For schools it can be useful to take an existing program as a starting point for the development of social-emotional skills among their students. However, it is not always clear whether the reported effectiveness of such programs can be expected among the own population of students. Many programs have been developed in different countries, with divergent educational systems. In addition, the reported effectiveness of the program should be seen in relation to specific aspects of the program. In some cases, specific groups of students are targeted, e.g., students that show behavioural problems in school. Other programs are designed for the average student in a school. The instruments that are used to implement and evaluate the programs might not always be available or suited for the context of the school.

It is crucial to spend time to adapt the program to one's own context, where not only the problem at hand, but also the goals of the program should be kept in mind. Attention has to be paid to effective monitoring and a relevant methodological approach therein, to be able to reach valid conclusions about the effects and make proper decisions on how to continue. In my research I not only want to contribute to knowledge about what works in education, but especially about why some programs work and under which conditions they are effective ${ }^{34}$. This implies the need for comprehensive information about the context of the program.

Together with Carla Haelermans I supervise Mélanie Monfrance, who works on a $\mathrm{PhD}$ research on the effectiveness of programs that schools develop for students in the transition from primary to secondary school. We explicitly focus on programs targeted at social-emotional skill development and the reduction of inequalities. The programs largely differ between the schools,

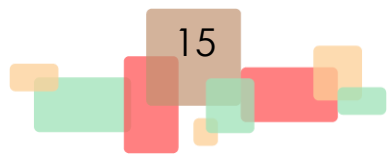


ranging from test classes in secondary school to the establishment of a middle school. Next to monitoring students' progress, we pay a lot of attention to understanding the motives behind the various programs and the goals that the schools have. This information is crucial to conclude on what works, why it works, and under which conditions. This means we spend a lot of time talking to educational practitioners. With this I come to my research approach.

\section{Research approach chair 'Economics of Education'}

The examples I used show that we already know some things about the relevance of different skills in education, and their impact on learning outcomes, yet still a lot is unknown. The answers are part of a more complex puzzle to solve. To really get to grips with the mechanisms behind the important relations and to develop effective programs that foster students' development, collaboration is necessary between relevant stakeholders, and complementary expertise needs to be used. This is central to my research approach.

My starting point is the economics of education. One could argue that research in the field of economics of education is in its third generation. Since the late 1950s, economists recognised the importance of investments in people's human capital, i.e., the collection of all individual skills and abilities, as one of the drivers of economic growth and the reduction of poverty. Questions addressed in this generation were largely theoretical and included why and how much people invest in education, how it affects their income profile, whether investments are optimal both on an individual and a societal level, how such investments contribute to economic growth, and whether and to what extent governments (or firms) should intervene in education or finance it. An important contribution was made by Gary Becker who formally introduced the human capital theory. He was the first to formally model people's skill formation as an investment, subject to individual choices ${ }^{35}$.

In the 1990s, a second generation of research on the economics of education started which was mostly empirical in nature. Economists were interested in estimating the monetary and non-monetary returns to the

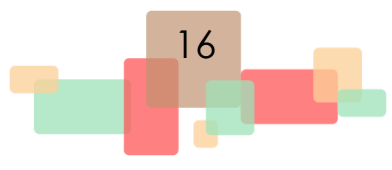


investments in education on the individual and aggregate level, explicitly addressing measurement issues ${ }^{36}$. For example, a cross-sectional comparison of returns was likely to overstate the returns to education or the relation between education and growth, because of selection biases. Using methodological approaches including instrumental variable methods, regression discontinuities, and (natural) experiments, causal effects of educational interventions have been investigated.

Recent research in the economics of education brings together the theoretical approach of the first generation with the empirical rigor of the second generation. The literature from the second generation showed several issues, including heterogeneous treatment effects, or different results from different experimental studies, which shows the need to go back to theory. For example, empirical evidence on the shortcomings of cognitive ability as a sole predictor of several life outcomes, has led to pioneer work on the formal inclusion of other skills into the human capital production function, and its relation to economic growth ${ }^{37}$. At the same time, it is recognized that empirical evidence and appropriate data are necessary for the development and evaluation of innovations in educational practice ${ }^{38}$. For example, a lot of attention is being paid to the study of instruments that are used to measure student performance, such as achievement tests, and what they actually measure ${ }^{39}$. Moreover, it is emphasised that experimental research is needed, that calls for collaboration with educational practitioners ${ }^{40}$. My research approach is positioned within this third generation of economics of education and characterised by the beforementioned four ingredients.
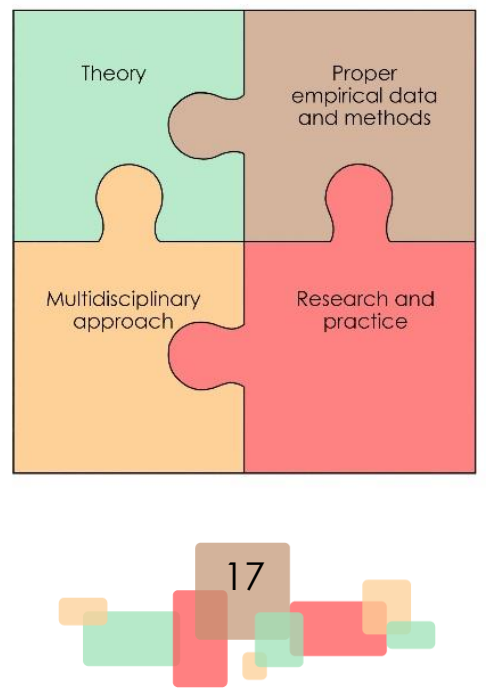
The use of theory is the first ingredient. In my research I rely on theoretical economic models to study decision-making. I will contribute to the development of such models, based on the insights about the development of the various skills in education and their relationship with learning outcomes. In doing so, I am particularly interested in the role of social-emotional skills, but also that of expectations and beliefs.

Second ingredient is a critical view on and development of proper data and methods to analyse the relations of interest. I will always ask myself whether I measure what I intend to measure, and which factors affect the measurement. An example is the contribution I intend to make to the development of instruments for teachers to assess students' socialemotional skills. This not only helps teachers to acquire the right information they need to make choices with respect to how to support students, but it also contributes to research by providing a valid view on social-emotional learning of students.

Third ingredient is a multidisciplinary approach. Research to the learning development and performance of students calls for different scientific disciplines. Psychology is key as many aspects of learning are related to mental processes and the development of children. For the study of inequalities in education, the sociological perspective is highly relevant. Educational sciences are necessary to make the connection to didactics in the classroom. For the development of the instruments for the assessment of social-emotional skills, I will actively seek collaboration with psychometricians, who have knowledge about constructing valid instruments. In my examples I named various people, among which noneconomists such as sociologists, psychologists, educational scientists, and health researchers. I already learned a lot from these collaborations and will continue to actively seek them. Such collaborations do not come naturally, and one must devote time to get to know each other. Sometimes we mean the same things, but use different terms, but sometimes we mean different things. It is important to understand each other.

Fourth ingredient is collaboration with educational practice. It is often mentioned that the research-practice relation is not an easy one ${ }^{41}$. Education practitioners do not always have access to research findings and if they do so, they experience difficulties in implementing the results

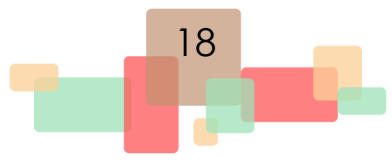


into their daily practice. Researchers are looking for generalisable knowledge and do not always take questions from educational practice as a starting point. Even if they do, the translation from research results into practical tools is difficult. Bridging the research-practice gap requires more sustainable collaboration between people from both sides, where time to invest in the relationship, understanding of each other's playing field and efficient communication are important elements ${ }^{42}$. Internationally, a growth of research-practice partnerships in education is observed, varying from collaboration on educational innovations on the classroom level to more general knowledge networks in which broader challenges are addressed, such as reducing inequalities in education ${ }^{43}$.

An example of such a sustainable research-practice partnership is the 'Educatieve Agenda Limburg', that was formally established in 2014 by merging existing initiatives ${ }^{44}$. It is a knowledge network where partners from primary to higher education, and the local government are represented. The partnership provides an important platform for connecting partners for projects and contributes to evidence-based education. Dialogue between relevant stakeholders, for example in learning communities, is a central element and necessary to get a sharp view on the challenges that the partners face and to understand the mechanisms that play a role. Moreover, it is recognised that for most successful educational innovations collaboration between partners from the different educational sectors is needed, and with stakeholders from outside education. Students' development must be viewed from a systemic perspective, where the student cannot be detached from his social environment. This again shows the relevance of multiple perspectives and complementarity of expertise. Of course, this is not easy and requires a step-by-step approach that partners must take together. In my research I also want to contribute to the understanding of the co-creation processes behind bridging the researchpractice gap in education.

Research as a central pillar of the Educatieve Agenda Limburg, also includes monitoring. To get a clear picture of the challenges that the partners face, it is crucial, next to dialogue and knowledge building, to systematically, and not ad hoc or temporary, acquire a broad set of data about students' development. In our region, we already do so for more than ten years, in a regional monitor (the OnderwijsMonitor Limburg), where 
information about students' cognitive and social-emotional development is merged and supplemented with additional surveys where necessary. The challenges mentioned in the collaboration between research and practice also apply to the use of data in education. By means of co-creation with educational practitioners, I will contribute to a more effective use of data by teachers and other professionals in education. Together deciding on what information is needed, whether existing instruments are sufficient, or whether other instruments are needed. For example, next to information about students, information about teachers is necessary, to reveal the relationships between teacher education or training and students' development. The continuous development of our regional monitor that fits the needs of involved stakeholders, supports educational innovations, prevents similar data collections, and facilitates a comparison in the region, also over time. The earlier mentioned example about school dropout, but also the recent information need because of the COVID-19 pandemic, shows how useful this can be. It provides insights that are not delivered with ad hoc or individual school data.

In sum, with the research in my chair 'Economics of Education' I actively look for the complementary expertise of other scientific disciplines and partners from educational practice, use scientific theory, proper data, and empirical methods to contribute to our understanding of the relevant skills that students need. With this, I want to support science, practice, and policy in the development to a sustainable and inclusive knowledge economy.

\section{Acknowledgements}

Finally, I want to express my gratitude to some people. I want to thank the members of the Solberg-Verlinden Foundation, the family of Mr. Solberg and Mrs. Verlinden and the University Fund for the faith they have in me and the creation of the endowed chair. I also thank my head of department, Dean and Rector for their faith in me and their support of the chair in Economics of Education.

I also want to thank everybody else that contributed to who I am, as a person and as a researcher. Those who are here today, and actively contributed to me standing here. You represent the complementary

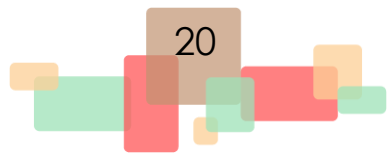


expertise I have been talking about. I very much enjoyed having you here. But I also want to thank all my other colleagues from in- and outside Maastricht University, including those from previous jobs at the Universities of Amsterdam and Tilburg. Of course, also people I did not explicitly mention in my lecture. Teachers, school leaders, other educational professionals, and policymakers from municipalities, regional and national government, or other organisations I collaborate with. Thanks also to those that viewed or listened through the livestream, for the interest in my lecture. Thank you to my beloved family and friends. Mam and dad, thank you very much for the solid base you gave me, the trust, room and love I received from you. And finally, Maus, thank you so much for being my best buddy for so long, the patience you have with me, and above all thank you for all the fun we have together.

I have said. 


\section{Notes}

1 Autor, David. 2013. The task approach to labor markets: An overview. Journal of Labour Market Research, 46 (3): 185-199.

Autor, David, Frank Levy, \& Richard Murnane. 2003. The skill content of recent technological change: An empirical exploration. Quarterly Journal of Economics, 118 (4): 1279-1333.

2 Brynjolfsson, Erik, Tom Mitchell, \& Daniel Rock. 2018. What can machines learn, and what does it mean for occupations and the economy? AEA Paper Proceedings, 108, 43-47.

Cohn, Jonathan. 2013. The robot will see you now. The Atlantic, February 20.

3 Frey, Carl \& Michael Osborne. 2013. The future of employment: How susceptible are jobs to computerisation. Working paper Oxford Martin Programme on Technology and Employment, University of Oxford.

4 Allen, Jim, Barbara Belfi, \& Lex Borghans. 2020. Is there a rise in the importance of socioemotional skills in the labor market? Evidence from a trend study among college graduates. Frontiers in Psychology, 11 (1710), 113.

Borghans, Lex, Bas Ter Weel, \& Bruce Weinberg. 2014. People skills and the labor market outcomes of underrepresented groups. Industrial and Labor Relations Review, 67 (2), 287-334.

Fouarge, Didier. 2017. Veranderingen in werk en vaardigheden. Inaugurele rede. Maastricht University.

5 Spengler, Marion, Rodica Damian, \& Brent Roberts. 2018. How you behave in school predicts life success above and beyond family background, broad traits, and cognitive ability. Journal of Personality and Social Psychology, 114 (4), 620-636.

6 Kautz, Tim, James Heckman, Ron Diris, Bas Ter Weel, \& Lex Borghans. 2014. Fostering and measuring skills: Improving cognitive and non-cognitive skills to promote lifetime success. NBER Working paper no. 20749. (revised in 2017). Cambridge: NBER.

Roberts, Brent, Nathan Kuncel, Rebecca Shiner, Avshalom Caspi, \& Lewis Goldberg. 2007. The Power of personality - The comparative validity of personality traits, socioeconomic status, and cognitive ability for predicting important life outcomes. Perspectives on Psychological Science, 2 (4), 313345.

7 Aschwanden, Damaris, Jason Strickhouser, Amanda Sesker, Ji Hyun Lee, Martina Luchetti, Yannick Stephan, Angelina Sutin, \& Antonio Terracciano. 
2020. Psychological and behavioural responses to Coronavirus disease 2019: The role of personality. European Journal of Personality, 35 (1), 51-66.

Asselmann, Eva, Lex Borghans, Raymond Montizaan, \& Philipp Seegers. 2020. The role of personality in the thoughts, feelings, and behaviors of students in Germany during the first weeks of the COVID-19 pandemic. PLoS ONE, 15 (11), 1-14.

Connor-Smith, Jennifer, \& Celeste Flachsbart. 2007. Relations between personality and coping: A meta-analysis. Journal of Personality and Social Psychology, 93 (6), 1080-1107.

Iterbeke, Kaat, \& Kristof De Witte. 2020. Helpful or harmful? The role of personality traits in student experiences of the COVID-19 crisis and school closure. Department of Economics KU Leuven Working Paper DPS 20.19.

Kroencke, Lara, Katharina Geukes, Till Utesch, Niclas Kuper, \& Mitja Back. 2020. Neuroticism and emotional risk during the COVID-19 pandemic. Journal of Research in Personality, 89 (104083).

8 Cornwell, Christopher M., David Mustard, \& Jessica Van Parys. 2013. Noncognitive skills and the gender disparities in test scores and teacher assessments: Evidence from primary school. Journal of Human Resources. 48 (1), 236-264.

Duckworth, Angela Lee, Patrick Quinn, Donald Lynam, Rolf Loeber, \& Magda Stouthamer-Loeber. 2011. Role of test motivation in intelligence testing. Proceedings of the National Academy of Sciences of the United States of America, 108 (19), 7716-7720.

Eklof, Hanna. 2007. Test-taking motivation and mathematics performance in TIMSS 2003. International Journal of Testing 7 (3), 31 1-327.

Golsteyn, Bart, \& Trudie Schils. 2014. Gender gaps in primary school achievement: A decomposition into endowments and returns to $I Q$ and non-cognitive factors. Economics of Education Review, 41, 176-187.

Spinath, Birgit, Harald Freudenthaler, \& Aljoscha Neubaver. 2010. Domainspecific school achievement in boys and girls as predicted by intelligence, personality and motivation. Personality and Individual Differences, 48, 481486.

9 Borghans, Lex, \& Trudie Schils. 2018. Decomposing achievement test scores into measures of cognitive and noncognitive skills, SSRN Working Paper Series.

10 Van der Steeg, Mark, \& Dinand Webbink. 2006. Voortijdig schoolverlaten in Nederland: omvang, beleid en resultaten. CPB Discussiepaper no. 107, Den Haag, Centraal PlanBureau. 
11 Ter Bogt, Tom, Maurice van Lieshout, Suzan Doornwaard, \& Yke Eijkemans. 2009. Middelengebruik en voortijdig schoolverlaten. Twee onderzoeken naar de actuele en gepercipieerde rol van alcohol en cannabis in relatie tot spijbelen, schoolprestaties, motivatie en uitval. Trimbos-instituut, Utrecht.

12 Dicks, Alexander, Mark Levels, \& Rolf van der Velden. 2020. From school to where? How social class, skills, aspirations, and resilience explain unsuccessful school-to-work transitions. Maastricht University, Graduate School of Business and Economics. GSBE Research Memoranda No. 013.

13 Diris, Ron, \& Trudie Schils. 2017. Voortijdig schoolverlaten in Zuid-Limburg: analyse van risicofactoren. Onderzoeksrapport Educatieve Agenda Limburg in opdracht van Stichting SVOPL, Heerlen.

14 Wehner, Caroline, \& Trudie Schils. 2021. Who are the low educational achievers? An analysis in relation to gender, emotional stability and conscientiousness. Applied Economics, forthcoming.

15 Diris, Ron, Lex Borghans, \& Trudie Schils. 2017. Citoscore en schooladvies: verschillen verklaard. Webtijdschrift Educatieve Agenda Limburg, januari 2017.

Dronkers, Jaap, \& Roxanne Korthals. 2016. Tracking in the Netherlands Ability selection or social reproduction? In: Blossfeld, Hans-Peter, Sandra Buchholz, Jan Skopek, \& Moris Triventi, (eds.), Models of Secondary Education and Social Inequality - An International Comparison, pp. 149165, Edward Elgar Publishing, Cheltenham (UK).

Korpershoek, Hanke, Carien Beijer, Marinda Spithoff, Harm Naaijer, Anneke Timmermans, Maaike van Rooijen, \& Naomi Van Rijn. 2016. Overgangen en aansluitingen in het onderwijs. GION, Groningen.

16 Feron, Eva. 2018. The role of cognitive tests and teachers in the transition from primary to secondary education. PhD. thesis School of Business and Economics, Maastricht University.

Montgomery, Diane. 2020. Tackling Disadvantage and Underachievement in Schools: a Practical Guide for Teachers. Routledge, London.

West, Anne, \& Hazel Pennell. 2003. Underachievement in Schools. Routledge, London.

17 Acacio-Claro, Paulyn J., Leena Koivusilta, David Doku, \& Arja Rimpelä. 2019. Timing of puberty and reserve capacity in adolescence as pathways to educational level in adulthood-a longitudinal study. Annals of Human Biology, 46 (1), 35-45. 
18 Geven, Sara, \& Herman van de Werfhorst. 2020. The role of cognitive tests and teachers in the transition from primary to secondary education. Sociology of Education, 93 (1), 40-64.

Geven, Sara, Jeroen Weesie, \& Frank van Tubergen. 2013. The influence of friends on adolescents' behavior problems at school: The role of ego, alter and dyadic characteristics. Social Networks, 35 (4), 583-592.

Muskens, Marjolein. Hidden obstacles in education for students from low socioeconomic backgrounds. PhD. thesis School of Business and Economics, Maastricht University.

Wentzel, Kathryn. 2017. Peer relationships, motivation, and academic performance at school. In Andrew Elliot, Carol Dweck, \& David Yeager (Eds.), Handbook of competence and motivation: Theory and application, p. 586-603, The Guilford Press.

19 Schwabe, Franziska, Roxanne Korthals, \& Trudie Schils. 2019. Positive social relationships with peers and teachers as moderators of the Big-Fish-LittlePond Effect. Learning and Individual Differences, 70, 21-29.

20 Golsteyn, Bart, Arjan Non, \& Ulf Zölitz. 2021. The impact of peer personality on academic achievement. Journal of Political Economy, 129 (4), 1052 1099.

21 Claes, Elke. 2020. Performance and expectations of prospective firstgeneration students. Master thesis School of Business and Economics, Maastricht University.

Gordin, Liza. 2019. Equity in the transition to higher education of prospective first-generation students in Limburg. Bachelor thesis University College, Maastricht University.

22 Hoxby, Caroline, \& Sarah Turner. 2015. What high-achieving low-income students know about college. The American Economic Review, 105 (5), 514 517.

Lewis, Neil jr., \& Frank Yates. 2019. Preparing disadvantaged students for success in college: Lessons learned from the preparation initiative. Perspectives on Psychological Science, 14 (1), 54-59.

O'Sullivan, Katriona, James Robson, \& Niall Winters. 2019. 'I feel like I have a disadvantage': how socio-economically disadvantaged students make the decision to study at a prestigious university. Studies in Higher Education, 44 (9), 1676-1690.

23 Borghans, Lex, \& Trudie Schils. 2011. Een schets voor een adaptieve toets voor het funderend onderwijs. Notitie voor het Ministerie van Onderwijs, Cultuur en Wetenschap, Maastricht University. 
24 Goertzen, Lars. 2020. Formatief evalueren in het basisonderwijs: Co-creatie als conditie voor duurzame implementatie. Presentatie gegeven op online festival SLO Formatief Evalueren.

25 de Bruin, Anique. 2020. Zelf leren sturen. Inaugurele rede. Maastricht University.

26 Dignath, Charlotte, \& Gerhard Büttner. 2008. Components of fostering selfregulated learning among students: a meta-analysis on intervention studies at primary and secondary school level. Metacognition and Learning, 3, 231-264.

27 Borghans, Lex, Ron Diris, \& Trudie Schils. 2021. The teacher or the test? An analysis of the short and long-run predictive power of achievement indicators. Unpublished manuscript, School of Business and Economics, Maastricht University.

Feron, Eva, Trudie Schils, \& Bas Ter Weel. 2016. Does the teacher beat the test? The additional value of teacher assessment in predicting student ability. De Economist, 164 (4), 391-418, 2016.

Jackson, Kirabo. 2018. What do test scores miss? The importance of teacher effects on non-test score outcomes. Journal of Political Economy 126 (5), 2072-2107.

Südkamp, Anna, Johanna Kaiser, \& Jens Möller. 2012. Acuracy of teachers' judgments of students' academic achievement: a Meta-analysis. Journal of Educational Psychology, 104 (3), 743-762.

28 Feron, Eva. 2018. The role of cognitive tests and teachers in the transition from primary to secondary education. PhD. thesis School of Business and Economics, Maastricht University.

29 Golle, Jessika, Trudie Schils, Lex Borghans, \& Norman Rose. 2021. Who is considered gifted from a teacher's perspective? A representative largescale study. Unpublished manuscript, Hector Research Institute of Education Sciences and Psychology, University of Tübingen.

30 Ledoux, Guuske, Joost Meijer, Ineke van der Veen, \& Iris Breetvelt. 2013. Meetinstrumenten voor sociale competenties, metacognitie en advanced skills: Een inventarisatie. Kohnstamm Instituut, Amsterdam.

Meissel, Kane, Frauke Meyer, Esther Yao, \& Christine Rubie-Davies. 2017. Subjectivity of teacher judgments: Exploring student characteristics that influence teacher judgments of student ability. Teaching and Teacher Education, 65, 48-60.

Wigelsworth, Michael, Neil Humphrey, Afroditi Kalambouka, \& Ann Lendrum. 2010. A review of key issues in the measurement of children's

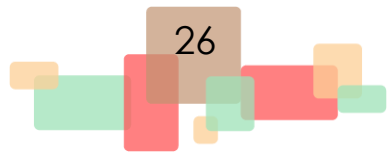


social and emotional skills. Educational Psychology in Practice, 26 (2), 173186.

31 De Groot, Adriaan. 1966. Vijven en zessen. Wolters, Groningen.

32 Stichting Solberg-Verlinden. 1999. Drs. J.W. ('Wiel') Solberg. 1921-1998. Ter herinnering.

33 Durlak, Joseph, Roger Weissberg, Allison Dymnicki, Rebecca Taylor, \& Kriston Schellinger. 2011 . The impact of enhancing students' social and emotional learning: A meta-analysis of school-based universal interventions. Child Development, 82, 405-432.

34 Gordon, Nora, \& Carrie Conaway. 2020. Common-sense evidence: The education leader's guide to using data and research. Harvard Education Publishing Group, Cambridge MA.

35 Becker, Gary. 1964. Human capital: a theoretical and empirical analysis, with special reference to education. The University of Chicago Press, Chicago.

36 Angrist, Joshua, \& Whitney Newey. 1991. Over-Identification tests in earnings functions with fixed effects. Journal of Business and Economic Statistics, 9 (3), 317-323.

Angrist, Joshua, \& Alan Krueger. 1992. The effect of age at school entry on educational attainment: An application of instrumental variables with moments from two samples. Journal of the American Statistical Association, 87 (418), 328-336.

Behrman, Jere, \& Victor Lavy, 1997. Child health and schooling achievement: Association, causality and household allocations, University of Pennsylvania: Institute of Economic Research.

37 Cunha, Flavio, \& James Heckman. 2008. Formulating, identifying and estimating the technology of cognitive and noncognitive skill formation. The Journal of Human Resources, 43 (4), 738-782.

Todd, Petra, \& Kenneth Wolpin. 2003. On the specification and estimation of the production function for cognitive achievement. The Economic Journal, 113 (485), 3-33.

38 Dee, Thomas, William Evans, \& Sheila Murray. 1999. Data Watch: Research data in the economics of education. Journal of Economic Perspectives, 13 (3), 205-216.

Hoxby, Caroline, \& Christopher Avery. 2013. The missing "One-Offs": The hidden supply of high-achieving, low-income students. Brookings Papers on Economic Activity, Spring, 1-50 
39 Borghans, Lex, Bart Golsteyn, James Heckman, \& John Erik Humphries. 2016. What Grades and Achievement Tests Measure. Proceedings of the National Academy of Sciences of the USA (PNAS), 113 (47), 13354-13359. Heckman, James J., John Erik Humphries, \& Tim Kautz. 2014. The myth of achievement tests: The GED and the role of character in American life. University of Chicago Press, Chicago.

40 Benhassine, Najy, Florencia Devoto, Esther Duflo, Pascaline Dupas, \& Victor Pouliquen. 2014. Turning a shove into a nudge? A "Labeled cash transfer" for education. NBER Working Paper No. 19227, Cambridge.

Fryer, Roland Jr., Steven Levitt, John List, \& Sally Sadoff. 2012. Enhancing the efficacy of teacher incentives through loss aversion: A field experiment. NBER Working Paper No. 18237, Cambridge.

Machin, Stephen, Sandra McNally, \& Costas Meghir. 2004. Improving pupil performance in English secondary schools: Excellence in cities. Journal of the European Economic Association, 2 (2-3), 396-405.

41 Broekkamp, Hein, \& Bernadette van Hout-Wolters. 2006. De kloof tussen onderwijsonderzoek en onderwijspraktijk: Een overzichtsstudie van problemen, oorzaken en oplossingen. Amsterdam University Press, Amsterdam.

van Tartwijk, Jan. 2011. Van onderzoek naar onderwijs, of de kunst van de toepassing. Inaugurele rede Universiteit Utrecht, 6 juni 2011.

42 Onderwijsraad. 2011. Ruim baan voor stapsgewijze verbeteringen. Advies No. 201 10293/998, Onderwijsraad, Den Haag.

Robinson, Viviane. 1998. Methodology and the research-practice gap. Educational Researcher, 27 (1).

MacMahon, Stephanie, Jack Legett, \& Annemaree Carroll. 2021. Building a bridge between research and educational practice. Teacher Bulletin.

43 Jonk, Esmee, Trudie Schils, Raoul Haenbeukers, Olaf van Egdom, Guido Timmermans, Henk Janssen, \& Gerlach van Wersch. 2017. Samen onderzoeken en leren: Onderzoekssamenwerking tussen onderwijspraktijk, wetenschap en beleid. SchoolManagement Totaal, 4, 28-31.

Penuel, William, \& Daniel Gallagher. 2017. Creating research-practice partnerships in education. Harvard Education Press, Cambridge MA.

Ziegler, Lauren. 2019. Storytelling and communities of research: Ideas for closing the research-practice gap in education. Wiseman, Alexander (Ed.) Annual review of comparative and international education 2019, Emerald Publishing Limited, Bingley, pp. 41-45.

44 www.educatieveagendalimburg.nl. 
Trudie Schils (1972, Maastricht), completed her studies in social and general economics at Tilburg University and showed an early interest in social questions (e.g., poverty and labour market issues). After her graduation she worked as a junior teacher at an Applied University in Den Bosch and Maastricht University, and did her PhD on early retirement behaviour at Tilburg University. She continued her academic career as a postdoctoral researcher at the University of Amsterdam and started in 2008 as an assistant professor at Maastricht University. In 2009 she was co-founder of a largescale regional educational monitor. In 2014 she became program leader of the Educatieve Agenda Limburg, a research-practice partnership in education where partners from all sectors and the regional government work together on educational challenges.

In her research she focuses on the role and limitations of the use of tests in education, the role of expectations and social-emotional skills in students' development, and differences between groups. Starting point in her research is that education can only be improved by good and structural collaboration between educational researchers from various disciplines, educational practitioners, and policymakers. Accordingly, she publishes in journals from various disciplines (e.g., economics, psychology, education), and in societal journals.

\section{TDUDIE SCHIIS \\ ONDERWIJSECONOOM}

